This journal is the official publication of Bangladesh Society of Physiologists (BSP)

Web URL: www.banglajol.info/index.php/JBSP

Abstracted/indexed in Index Copernicus, Director of Open Access Journal, HINARI Index Medicus for South East Asia Region, Google Scholar, 12OR, infobse index, Open J gate, Cite factor, Scientific indexing services

pISSN-1983-1213; e-ISSN-2219-7508

\title{
Article
}

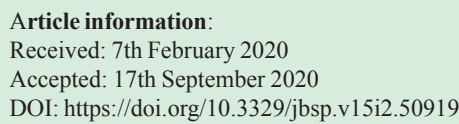

This article is open access licensed under CC BY NC SA which allows readers copy, distribute, display, and perform the work and make derivative works based on it only for noncommercial purposes.

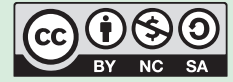

\section{Morphometric study of the size of the postmortem human kidney}

\author{
Fatema Johora', Abu Sadat Mohammad Nurunnabi², \\ Dilruba Siddiqua ${ }^{3}$, Hasna Hena ${ }^{4}$, Shamim $\mathrm{Ara}^{5}$ \\ 1. Department of Anatomy, Sir Salimullah Medical College, Dhaka \\ 2. OSD, Department of Anatomy, Directorate General of Health Services \\ (DGHS), Dhaka. \\ 3. Department of Anatomy, Ibn Sina Medical College, Dhaka. \\ 4. Department of Anatomy, East-West Medical College, Dhaka. \\ 5. Department of Anatomy, Holy Family Red Crescent Medical College, \\ Dhaka.
}

\section{Abstract}

Background: Changes in the size of the kidney are evident in humans, as age progresses. Objective: To see the age-related changes in the morphological dimensions of the kidney in a sample of the Bangladeshi population. Methods: This crosssectional study was done in the Department of Anatomy, Dhaka Medical College, Dhaka, from July 2008 to June 2009, based on a collection of 140 postmortem human kidneys collected from 70 unclaimed dead bodies from the morgue of the same institution. All the samples of kidney were divided into three age groups, including A (10-19 years), B (20-39 years) and C (40-59 years). The length, breadth and thickness of all the kidneys were measured by using a slide calipers and recorded. Data were expressed as mean \pm SD. For statistical analysis, independent sample t test and one way ANOVA was used. Results: The length of the right and left kidneys found were $8.72 \pm 0.25 \mathrm{~cm}$ and $9.28 \pm 0.12 \mathrm{~cm} ; 9.73 \pm 0.35 \mathrm{~cm}$ and $10.31 \pm 0.41 \mathrm{~cm} ; 9.68 \pm 0.21$ $\mathrm{cm}$ and $10.24 \pm 0.06 \mathrm{~cm}$ in group $\mathrm{A}, \mathrm{B}$ and $\mathrm{C}$ respectively. The breadth of the right and left kidneys found were $4.32 \pm 0.09 \mathrm{~cm}$ and $4.22 \pm 0.11 \mathrm{~cm} ; 4.74 \pm 0.29 \mathrm{~cm}$ and $4.55 \pm 0.28 \mathrm{~cm} ; 4.61 \pm 0.21$ $\mathrm{cm}$ and $4.44 \pm 0.21 \mathrm{~cm}$ in group $\mathrm{A}, \mathrm{B}$ and $\mathrm{C}$ respectively. The thickness of the right and left kidneys found were $2.84 \pm 0.10 \mathrm{~cm}$ and $2.64 \pm 0.05 \mathrm{~cm} ; 3.31 \pm 0.16 \mathrm{~cm}$ and $3.11 \pm 0.10 \mathrm{~cm} ; 3.17 \pm 0.07$ $\mathrm{cm}$ and $3.11 \pm 0.10 \mathrm{~cm}$ in group $\mathrm{A}, \mathrm{B}$ and $\mathrm{C}$ respectively. The mean length of the left kidneys was found significantly greater than that of the right, whereas the mean breadth and the thickness of the right kidneys were found greater than that of the left kidney 
in all age groups. Moreover, age related changes were significant in all dimensions (length, breadth and thickness) of the kidney when compared between group A \& B and A \& C. Conclusion: This study results concluded that the length of the left kidney was greater than that of the right, but the breadth and the thickness of the right kidney were greater than that of the left one in all age groups. In addition, age related changes in all dimensions (i.e. length, breadth and thickness) of the kidneys were evident in middle age versus young adult and older adult versus young adult.

Key words: Morphometry, human kidney, length, breadth, thickness.

\section{Introduction}

A geing is a biologic process from which no life being exempt, and universal effect of ageing is evident by the gradual loss of functioning cells among many organs and tissues. Evidence shows that progressive deterioration of renal function and structure is in place, as age progresses ${ }^{1}$. Studies found that renal mass declines along with its dimensions in older adults. ${ }^{2-4}$ The study of the morphological changes with age and the effects that they may have on renal morbidity have become research interest both for its scientific and clinical consequences. ${ }^{5}$ For example, kidneys with length less than $8 \mathrm{~cm}$ are regarded as a contraindication for the intervention of renal arterial disease. ${ }^{6}$ In some other evidence showed that renal size increases up to a certain age, and renal enlargement eventually occurs in $100 \%$ of patients with Autosomal Dominant Polycystic Kidney Disease (ADPKD). ${ }^{7-8}$ Sometimes, such massive renal enlargement can lead to compression of local structures, resulting in such complications as inferior vena cava compression and digestive symptoms. ${ }^{7}$ Most of the manifestations are directly related to the development and enlargement of renal cysts. ${ }^{8}$ Therefore, measurement of kidney size is the most sensitive and specific noninvasive test to establish the chronicity of renal disease. ${ }^{8}$ Exact knowledge of the normal morphometry e.g. the length, breadth and thickness of the kidney, facilitates the urologists, nephrologists, pathologists and sonologists to diagnose and adopt appropriate plan for treatment in various clinical conditions of the kidney. ${ }^{9}$ It has also been observed by various researchers that the dimensions of different organs in Bangladeshi population have got variations from those of the western population. ${ }^{10}$ Therefore, the present study was designed to see the variations in dimensions i.e. length, breadth and thickness of human kidney in a Bangladeshi population and to compare with previous local and foreign findings.

\section{Methods}

This cross-sectional, study was done in the Department of Anatomy, Dhaka Medical College, Dhaka, from July 2008 to June 2009. The present study protocol was approved by the Ethical Review Committee of Dhaka Medical College, Dhaka, Bangladesh.

For this study, 140 post mortem human kidney samples were collected by purposive sampling technique from 70 unclaimed male and female dead bodies in the morgue under examination in the Department of Forensic Medicine, Dhaka Medical College, Dhaka. All the samples were taken from medicolegal cases but excluded cases of poisoning, any cutting or crushing injury to the kidneys, kidney found in one side or grossly abnormal in shape/size. For a convenient description of the changes of the morphological dimensions of the kidney in relation to age $^{2}$, the collected samples were divided into three age groups: A (10-19 years), B (20-39 years) and C (40-59 years) (Table I). 
Table I: Age ranges of the samples of the present study $(\mathrm{n}=140)$

\begin{tabular}{|c|c|c|c|}
\hline$\overline{\text { Age }}$ & Age limit & Number o & samples \\
\hline group & in years & Right kidney & Left kidney \\
\hline A & $10-19$ & 12 & 12 \\
\hline B & $20-39$ & 43 & 43 \\
\hline C & $40-59$ & 15 & 15 \\
\hline
\end{tabular}

After removing the kidneys from the cadavers, their outer surface was dried with blotting paper. Then the length, breadth and thickness of all the kidney samples were measured by using a slide calipers and recorded. The length was measured at maximum distance from upper pole to lower pole, while the breadth was measured at the maximum transverse diameter in the middle portion of the kidney at the level of its hilum and the thickness was measured at the region of its maximum anterior-posterior diameter near its midpoint. ${ }^{11}$

The collected data were processed and statistical analyses were done by using SPSS version 13.0. Data were expressed as mean \pm SD. The comparison between the right and the left kidney was done by using independent sample ' $t$ ' test and in between different groups were done by One-way ANOVA post hoc test.
Results

In this study, the length of the right and left kidneys found were $8.72 \pm 0.25 \mathrm{~cm}$ and $9.28 \pm 0.12$ $\mathrm{cm} ; 9.73 \pm 0.35 \mathrm{~cm}$ and $10.31 \pm 0.41 \mathrm{~cm} ; 9.68 \pm 0.21$ $\mathrm{cm}$ and $10.24 \pm 0.06 \mathrm{~cm}$ in group A, B and C respectively (Table II). The breadth of the right and left kidneys found were $4.32 \pm 0.09 \mathrm{~cm}$ and $4.22 \pm 0.11 \mathrm{~cm} ; 4.74 \pm 0.29 \mathrm{~cm}$ and $4.55 \pm 0.28 \mathrm{~cm}$; $4.61 \pm 0.21 \mathrm{~cm}$ and $4.44 \pm 0.21 \mathrm{~cm}$ in group A, B and $\mathrm{C}$ respectively (Table III). The mean thickness of the right and left kidneys found were $2.84 \pm 0.10 \mathrm{~cm}$ and $2.64 \pm 0.05 \mathrm{~cm} ; 3.31 \pm 0.16 \mathrm{~cm}$ and $3.11 \pm 0.10 \mathrm{~cm} ; 3.17 \pm 0.07 \mathrm{~cm}$ and $3.11 \pm 0.10$ $\mathrm{cm}$ in group $\mathrm{A}, \mathrm{B}$ and $\mathrm{C}$ respectively (Table IV). The mean length of the left kidneys was found significantly greater than of the right (Table II), while the mean breadth and the thickness of the right kidneys were found greater than that of the left kidneys (Table III \& IV) in all age groups. In addition, the mean values depicting the size of the kidney samples considering all dimensions (length, breadth and thickness) of the kidney were found significantly greater in group $\mathrm{B}$ compared to $\mathrm{A}$ and also in $\mathrm{C}$ compared to A (Table II, III $\&$ IV). There was no significant difference in kidney size when compared between group $\mathrm{B}$ and group C.

Table II: Length of right and left kidney in different age group

\begin{tabular}{llll}
\hline Age Group & \multicolumn{2}{c}{ Length in cm } & P value \\
\cline { 2 - 3 } & $\begin{array}{l}\text { Right Kidney } \\
\text { Mean } \pm \text { SD }\end{array}$ & $\begin{array}{l}\text { Left Kidney } \\
\text { Mean } \pm \text { SD }\end{array}$ & \\
\hline $\mathrm{A}(\mathrm{n}=12)$ & $8.72 \pm 0.25(8.20-8.95)$ & $9.28 \pm 0.12(9.00-9.40)$ & $<0.001$ \\
$\mathrm{~B}(\mathrm{n}=43)$ & $9.73 \pm 0.35(9.10-10.40)$ & $10.31 \pm 0.41(9.50-10.90)$ & $<0.001$ \\
$\mathrm{C}(\mathrm{n}=15)$ & $9.68 \pm 0.21(9.30-10.10)$ & $10.24 \pm 0.06(10.10-10.30)$ & $<0.001$ \\
& P value & P value & \\
A vs B & $<0.001$ & $<0.001$ & \\
A vs C & $<0.001$ & $<0.001$ & \\
$\mathrm{~B}$ vs C & $>0.50$ & $>0.10$ & \\
\hline
\end{tabular}

Figures in the parentheses indicate range. Comparison between right and left side done by independent sample ' $t$ ' test and comparison between different age groups done by One-way ANOVA (PostHoc),. Group A- 10-19 years, Group B-20-39 years Group C-40-59 years 
Table III: Breadth of right and left kidney in different age group.(N=140)

\begin{tabular}{llll}
\hline Age Group & \multicolumn{2}{c}{ Breadth in cm } & P value \\
& $\begin{array}{l}\text { Right Kidney } \\
\text { Mean } \pm \text { SD }\end{array}$ & $\begin{array}{l}\text { Left Kidney } \\
\text { Mean } \pm \text { SD }\end{array}$ & \\
\hline $\mathrm{A}(\mathrm{n}=12)$ & $4.32 \pm 0.09(4.10-4.40)$ & $4.22 \pm 0.11(4.00-4.38)$ & $<0.05$ \\
$\mathrm{~B}(\mathrm{n}=43)$ & $4.74 \pm 0.29(4.20-5.28)$ & $4.55 \pm 0.28(4.10-5.00)$ & $<0.01$ \\
$\mathrm{C}(\mathrm{n}=15)$ & $4.61 \pm 0.21(4.19-4.80)$ & $4.44 \pm 0.21(4.10-4.60)$ & $<0.05$ \\
& P value & P value & \\
$\mathrm{A}$ vs B & $<0.001$ & $<0.001$ & \\
$\mathrm{~A}$ vs C & $<0.01$ & $<0.05$ & \\
$\mathrm{~B}$ vs C & $>0.50$ & $>0.10$ & \\
\hline
\end{tabular}

Figures in the parentheses indicate range. Comparison between right and left side done by independent sample ' $\mathrm{t}$ ' test and comparison between different age groups done by One-way ANOVA (PostHoc),. Group A- 10-19 years, Group B-20-39 years Group C-40-59 years

Table IV: Thickness of right and left kidney in different age group

\begin{tabular}{llll}
\hline Age Group & \multicolumn{2}{c}{ Thickness in cm } & P value \\
& $\begin{array}{l}\text { Right Kidney } \\
\text { Mean } \pm \text { SD }\end{array}$ & $\begin{array}{l}\text { Left Kidney } \\
\text { Mean } \pm \text { SD }\end{array}$ & \\
\hline A & $2.84 \pm 0.10$ & $2.64 \pm 0.05$ & $<0.001$ \\
$(\mathrm{n}=12)$ & $(2.60-2.98)$ & $(2.60-2.70)$ & \\
$\mathrm{B}$ & $3.31 \pm 0.16$ & $3.11 \pm 0.10$ & $<0.001$ \\
$(\mathrm{n}=43)$ & $(2.90-3.26)$ & $(2.70-3.25)$ & \\
$\mathrm{C}(\mathrm{n}=15)$ & $3.17 \pm 0.07$ & $3.11 \pm 0.10$ & \\
& $(3.10-3.26)$ & $(3.00-3.23)$ & \\
& P value & P value & \\
A vs B & $<0.001$ & $<0.001$ & \\
A vs C & $<0.001$ & $<0.001$ & \\
B vs C & $<0.01$ & $>0.50$ & \\
\hline
\end{tabular}

Figures in the parentheses indicate ranges. Comparison between right and left side done by independent sample ' $\mathrm{t}$ ' test and comparison between different age groups done by One-way ANOVA (PostHoc),. Group A- 10-19 years, Group B-20-39 years Group C-40-59 years.

Discussion

Mullick $^{9}$ first observed the average measurements of kidney sample in Bangladeshi people are $9.9 \mathrm{~cm}$ in length, $4.6 \mathrm{~cm}$ in breadth and $3.7 \mathrm{~cm}$ in thickness. Sultana ${ }^{10}$ also examined
40 human kidneys and found the average length, breadth and thickness $8.00 \pm 0.44 \mathrm{~cm}, 4.40 \pm 0.15$ $\mathrm{cm}$ and $2.68 \pm 0.40 \mathrm{~cm}$ in male and $7.10 \pm 0.36 \mathrm{~cm}$, $4.60 \pm 0.15 \mathrm{~cm}$ and $1.90 \pm 0.25 \mathrm{~cm}$ in female in group A (10-20 years) respectively, while 
$10.06 \pm 0.23 \mathrm{~cm}, 5.42 \pm 0.18 \mathrm{~cm}$ and $2.66 \pm 0.18 \mathrm{~cm}$ in male and $9.23 \pm 0.14 \mathrm{~cm}, 6.20 \pm 0.15 \mathrm{~cm}$ and $2.26 \pm 0.24 \mathrm{~cm}$ in female in group B (21-40 years) respectively, and $9.26 \pm 0.22 \mathrm{~cm}, 5.28 \pm 0.24 \mathrm{~cm}$ and $2.48 \pm 0.31 \mathrm{~cm}$ in male and $8.35 \pm 0.05 \mathrm{~cm}$, $5.35 \pm 0.05 \mathrm{~cm}$ and $2.35 \pm 0.05 \mathrm{~cm}$ in female in group C (41-65 years) respectively. Alam ${ }^{11}$ studied on 60 postmortem kidneys and found the average length of kidney $7.29 \mathrm{~cm}$ in group A (515 years), $9.38 \mathrm{~cm}$ in group B (16-35 years) and $8.82 \mathrm{~cm}$ in group C (36-60 years), while the average breadth were $3.80 \mathrm{~cm}, 4.78 \mathrm{~cm}$ and 4.30 $\mathrm{cm}$ and the average thickness were $2.96 \mathrm{~cm}, 3.37$ $\mathrm{cm}$ and $3.63 \mathrm{~cm}$ in group $\mathrm{A}, \mathrm{B}$ and $\mathrm{C}$ respectively. Nahar et al. ${ }^{12}$ studied 120 cadaveric kidneys of age ranging from 12 to 65 years and found the length of the right and left kidneys were $7.44 \pm 0.89 \mathrm{~cm}$ and $7.49 \pm 0.84 \mathrm{~cm}$ in group A (1220 years), $9.92 \pm 1.23 \mathrm{~cm}$ and $9.88 \pm 1.27 \mathrm{~cm}$ in group B (21-40 years), $8.79 \pm 0.59 \mathrm{~cm}$ and $8.76 \pm 0.58 \mathrm{~cm}$ in group $\mathrm{C}$ (41-65 years). The breadth of the right and left kidneys found were $4.45 \pm 0.32 \mathrm{~cm}$ and $4.48 \pm 0.27 \mathrm{~cm} ; 5.36 \pm 0.56 \mathrm{~cm}$ and $5.35 \pm 0.53 \mathrm{~cm} ; 4.76 \pm 0.26 \mathrm{~cm}$ and $4.73 \pm 0.18$ $\mathrm{cm}$ in group $\mathrm{A}, \mathrm{B}$ and $\mathrm{C}$ respectively. The thickness of the right and left kidneys found were $2.70 \pm 0.17 \mathrm{~cm}$ and $2.71 \pm 0.16 \mathrm{~cm} ; 3.38 \pm 0.19 \mathrm{~cm}$ and $3.37 \pm 0.20 \mathrm{~cm} ; 3.31 \pm 0.09 \mathrm{~cm}$ and $3.31 \pm 0.12$ $\mathrm{cm}$ in group $\mathrm{A}, \mathrm{B}$ and $\mathrm{C}$ respectively. All the parameters showed age related differences except for thickness between B \& C. Banik et al. ${ }^{13}$ examined 49 human kidneys and found the length of the right and left kidneys were $7.62 \pm 0.86 \mathrm{~cm}$ and $7.87 \pm 0.93 \mathrm{~cm}$ in group A (620 years), $8.82 \pm 1.08 \mathrm{~cm}$ and $8.94 \pm 1.02 \mathrm{~cm}$ in group B (21-36 years) and $8.99 \pm 0.68 \mathrm{~cm}$ and $9.05 \pm 0.65 \mathrm{~cm}$ in group $\mathrm{C}$ (37-65 years) respectively. The breadth of the right and left kidneys found were $3.70 \pm 0.43 \mathrm{~cm}$ and $3.88 \pm 0.36$ $\mathrm{cm} ; 4.44 \pm 0.52 \mathrm{~cm}$ and $4.43 \pm 0.54 \mathrm{~cm} ; 4.30 \pm 0.48$ $\mathrm{cm}$ and $4.16 \pm 0.43 \mathrm{~cm}$ in group $\mathrm{A}, \mathrm{B}$ and $\mathrm{C}$ respectively. The thickness of the right and left kidneys were found $3.04 \pm 0.36 \mathrm{~cm}$ and $3.08 \pm 0.26$ $\mathrm{cm} ; 3.62 \pm 0.77 \mathrm{~cm}$ and $3.65 \pm 0.76 \mathrm{~cm} ; 3.40 \pm 0.35$ $\mathrm{cm}$ and $3.48 \pm 0.42 \mathrm{~cm}$ in group $\mathrm{A}, \mathrm{B}$ and $\mathrm{C}$ respectively. Khatun et al. ${ }^{14}$ studied 50 human subjects, aged from 11-80 years, and found the length $8.12 \mathrm{~cm}, 9.12 \mathrm{~cm}$ and $8.73 \mathrm{~cm}$; the breadth $4.46 \mathrm{~cm}, 4.31 \mathrm{~cm}$ and $3.58 \mathrm{~cm}$; the thickness 1.72 $\mathrm{cm}, 2.19 \mathrm{~cm}$ and $1.48 \mathrm{~cm}$ in group A (11-25 years), B (26-40 years) and C (41-80 years) respectively.

There are several evidences of the kidney measurement in western populations. According to Gardner, Gray \& O'Rahilly ${ }^{15}$ and Grant, Basmajian \& Slonecker ${ }^{16}$, the kidneys are about 11 to $13 \mathrm{~cm}$ long; the left one is somewhat longer and larger than the right. Emamian et al. ${ }^{17}$ examined 665 kidneys and found average length $10.9 \mathrm{~cm}$ and $11.2 \mathrm{~cm}$ in right and left kidney respectively, while average width were $5.7 \mathrm{~cm}$ and $5.8 \mathrm{~cm}$ respectively. Fawcett $\& \mathrm{Jensh}^{18}$ stated that kidneys are 10-12 cm in length, 5-6 cm in width and 3-4 cm in thickness. Healy ${ }^{19}$ reported that each kidney is about $11 \mathrm{~cm}$ in length, $6 \mathrm{~cm}$ in breadth and $3 \mathrm{~cm}$ in anterior posterior dimension. The left kidney may be $1.5 \mathrm{~cm}$ longer than the right one. Ellis \& Mahadevan ${ }^{20}$ reported that the kidney measures about $11 \mathrm{~cm}$ in length, $6 \mathrm{~cm}$ in width and $4 \mathrm{~cm}$ in thickness. Sinnatamby ${ }^{21}$ stated that the normal kidney measures about $12 \mathrm{~cm} \times 6 \mathrm{~cm} \times 3 \mathrm{~cm}$, while Ross $\&$ Pawlina $^{22}$ reported that each kidney measures approximately $10 \mathrm{~cm}$ long $\times 6.5 \mathrm{~cm}$ wide (from concave to convex border) $\times 3 \mathrm{~cm}$ thick. However, according to Moore, Dalley \& Agur $^{23}$, the kidney measures approximately $10 \mathrm{~cm}$ in length, $5 \mathrm{~cm}$ in width and $2.5 \mathrm{~cm}$ in thickness. Apart from few exceptions, the results of the present study are similar to that of previous records. Smaller size in some kidney specimens may attribute to racial variation and somewhat shrinkage resulting from fixation with formalin ${ }^{12}$. The minimal variations of kidney's dimension between Bangladeshi and Western people might result from higher body weight as well as greater body surface area of the Western population. ${ }^{14}$

Volume 15 No. 2 December 2020: 61-67 


\section{Conclusion}

In conclusion, the length of the left kidney was found greater than that of the right, while the breadth and the thickness of the right kidney were found greater than that of the left one in all age groups. Besides, age related changes were also evident in all dimensions (length, breadth and thickness) of the kidney among selective age groups. The results of the present study can be used as a standard reference for the kidneys of Bangladeshi people and may help to determine the abnormal evidences in forensic and pathological cases. However, further studies with larger samples and comparison between sexes are recommended.

Ethical Consideration This study was approved by Institutional Review Board of BSMMU, Dhaka

Conflict of interest: There is no conflict of interest relevant to this paper to disclose.

\section{Acknowledgement}

We would like to express our gratitude to the authority of Health, Nutrition \& Population Sector Programme (HNPSP) of Directorate General of Health Services (DGHS) of the Government of the People's Republic of Bangladesh, and Principal, Dhaka Medical College, Dhaka, for the research grant to support this study.

\section{References}

1. Anderson S, Brenner BM. Effects of aging on renal glomerulus. Am J Med 1986;80(3):435-42.

2. Darmady EM, Offer J, Woodhouse MA. The parameters of the ageing kidney. J Pathol 1973;109(3):195-207.

3. Nyengaard JR, Bendtsen TF. Glomerular number and size in relation to age, kidney weight, and body surface in normal man. Anat Rec 1992;232(2):194-201.

4. Hughson M, Farris AB, Douglus DR, Denten R, Hoy WE, Bertran JF. Glomerular number and size in autopsy kidney: the relationship to birth weight. Kidney Int 2003;63(3):2113-22.
5. Bonomini V, Vangelista A. Structural and functional renal changes in the elderly. Contrib Nephrol 1988;61:73-81.

6. Sylve'n M, Boyd M. Renal artery intervention - an invasive radiologist's approach. Saudi J Kidney Dis Transpl 2005;16(2):181-92.

7. Torres VE, Harris PC. Autosomal dominant polycystic kidney disease. In: Floege J, Johnson RJ, Feehally J. eds. Comprehensive clinical nephrology. 4th ed. Philadelphia: Saunders Elsevier; 2010: p.529-42.

8. Clarkson MR, Magee CN, Brenner BM. Clinical assessment of the patient with kidney disease. In: Pocket companion to Brenner and Rector's the Kidney. 8th ed. Philadelphia: Saunders Elsevier; 2011: p.3-20.

9. Mullick MH. The arterial pattern of human kidney. J Pak Med Assoc 1970;20:77-83.

10. Sultana Z. An Anatomical study of human postmortem kidney in Bangladeshi people [thesis]. Dhaka: IPGMR, University of Dhaka; 1991.

11. Alam MZ. Gross morphological and histological features of kidneys in Bangladeshi people [thesis]. Dhaka: IPGMR, University of Dhaka; 1994.

12. Nahar A, Hussain MA, Ara S, Begum J, Chowdhury AHMMM. Morphological study of postmortem human kidney. Bangladesh J Anat 2007;5(1):10-4.

13. Banik S, Shefyetullah KM, Naushaba H, Begum S, Khatun M, Rahman M. Gross dimension of postmortem kidney of Bangladeshi people in different age. J Dhaka Natl Med Coll Hosp 2007;12(2):9-13.

14. Khatun H, Sultana Z, Islam NAF, Kibria GM, Chowdhury TE. Morphological study of the kidney in relation to age. Bangladesh J Anat 2009;7(1):19-21.

15. Gardner E, Gray DJ, O’Rahilly R. Anatomy: a regional study of human structure. 5th ed. Philadelphia: WB Saunders; 1986.

16. Grant JCB, Basmajian JV, Slonecker CE. Grant's method of anatomy: a clinical problem-solving approach. 11th ed. Baltimore: Lippincott Williams \& Wilkins; 1989.

17. Emamian SA, Nielsen MB, Pedersen JF, Ytte L. kidney dimensions at sonography: correlation with age, sex and habitus in 665 adult volunteers. Am J Roentgenol 1993;160:83-6.

18. Fawcett DW, Jensh RP. Bloom and Fawcett's concise histology. 2nd ed. London: Arnold; 2002: p.237-9. 
19. Healy JC. Kidney and ureter. In: Standring S, Borley NR, Collins P, Crossman AR, Gatzoulis MA, Healy JC, et al. eds. Gray's anatomy: the anatomical basis of clinical practice. 40th ed. Edinburgh: Elsevier Churchill Livingstone; 2008: p.1225-38.

20. Ellis H, Mahadevan V. The urinary tract. Clinical anatomy: applied anatomy for students and junior doctors. 12th ed. Oxford: Wiley-Blackwell; 2010: p.112-5.

21. Sinnatamby CS. Kidneys, ureters and suprarenal glands. In: Last's anatomy: regional and applied. 12th ed. Edinburgh: Elsevier Churchill Livingstone; 2011: p.283-7.

22. Ross MH, Pawlina W. Histology: a text and atlas with correlated cell and molecular biology. 6th ed. Baltimore: Lippincott Williams \& Wilkins; 2011: p.698-714.

23. Moore KL, Dalley AF, Agur AMR. Kidneys, ureters, and suprarenal glands. In: Clinically oriented anatomy. 7th ed. B altimore: Lippincott Williams \& Wilkins; 2014: p.290-300. 